\title{
Phosphoglycerate Mutase 1 Prevents Neuronal Death from Ischemic Damage by Reducing Neuroinflammation in the Rabbit Spinal Cord
}

\author{
Hyo Young Jung ${ }^{1,+}+$, , Hyun Jung Kwon ${ }^{2,+}$, Woosuk Kim ${ }^{1,3}$, Kyu Ri Hahn ${ }^{1}$, \\ Seung Myung Moon ${ }^{4,5}$, Yeo Sung Yoon ${ }^{1}$, Dae Won Kim ${ }^{2, *}$ and In Koo Hwang 1,*D \\ 1 Department of Anatomy and Cell Biology, College of Veterinary Medicine, and Research Institute for \\ Veterinary Science, Seoul National University, Seoul 08826, Korea; hyoyoung@snu.ac.kr (H.Y.J.); \\ tank3430@hallym.ac.kr (W.K.); hkinging@snu.ac.kr (K.R.H.); ysyoon@snu.ac.kr (Y.S.Y.) \\ 2 Department of Biochemistry and Molecular Biology, Research Institute of Oral Sciences, College of Dentistry, \\ Gangneung-Wonju National University, Gangneung 25457, Korea; donuts25@gwnu.ac.kr \\ 3 Department of Biomedical Sciences, and Research Institute for Bioscience and Biotechnology, \\ Hallym University, Chuncheon 24252, Korea \\ 4 Department of Neurosurgery, Dongtan Sacred Heart Hospital, College of Medicine, Hallym University, \\ Hwaseong 18450, Korea; nsmsm@hallym.ac.kr \\ 5 Research Institute for Complementary \& Alternative Medicine, Hallym University, Chuncheon 24253, Korea \\ * Correspondence: kimdw@gwnu.ac.kr (D.W.K.); vetmed2@snu.ac.kr (I.K.H.) \\ + These authors are contributed equally to this article.
}

Received: 25 August 2020; Accepted: 1 October 2020; Published: 8 October 2020

\begin{abstract}
Phosphoglycerate mutase 1 (PGAM1) is a glycolytic enzyme that increases glycolytic flux in the brain. In the present study, we examined the effects of PGAM1 in conditions of oxidative stress and ischemic damage in motor neuron-like (NSC34) cells and the rabbit spinal cord. A Tat-PGAM1 fusion protein was prepared to allow easy crossing of the blood-brain barrier, and Control-PGAM1 was synthesized without the Tat peptide protein transduction domain. Intracellular delivery of Tat-PGAM1, not Control-PGAM1, was achieved in a time- and concentration-dependent manner. Immunofluorescent staining confirmed the intracellular expression of Tat-PGAM1 in NSC34 cells. Tat-PGAM1, but not Control-PGAM1, significantly alleviated $\mathrm{H}_{2} \mathrm{O}_{2}$-induced oxidative stress, neuronal death, mitogen-activated protein kinase, and apoptosis-inducing factor expression in NSC34 cells. After ischemia induction in the spinal cord, Tat-PGAM1 treatment significantly improved ischemia-induced neurological impairments and ameliorated neuronal cell death in the ventral horn of the spinal cord $72 \mathrm{~h}$ after ischemia. Tat-PGAM1 treatment significantly mitigated the ischemia-induced increase in malondialdehyde and 8-iso-prostaglandin $\mathrm{F} 2 \alpha$ production in the spinal cord. In addition, Tat-PGAM1, but not Control-PGAM1, significantly decreased microglial activation and secretion of pro-inflammatory cytokines, such as interleukin (IL)-1 $\beta$, IL-6, and tumor necrosis factor (TNF)- $\alpha$ induced by ischemia in the ventral horn of the spinal cord. These results suggest that Tat-PGAM1 can be used as a therapeutic agent to reduce spinal cord ischemia-induced neuronal damage by lowering the oxidative stress, microglial activation, and secretion of pro-inflammatory cytokines, such as IL-1 $\beta$, IL-6, and TNF- $\alpha$.
\end{abstract}

Keywords: phosphoglycerate mutase 1; ischemia; spinal cord; oxidative stress; pro-inflammatory cytokine

\section{Introduction}

Spinal cord ischemia is a subject of high interest in the field of neuroscience, and the current research focuses on understanding the pathophysiology of neuronal death after ischemia and 
identifying preventive or therapeutic agents to overcome ischemia-related neuronal damage [1,2]. Clinically, spinal cord ischemia and subsequent neuronal damage can be predicted, because interruption of the abdominal aorta is a medical requirement in cases of total en bloc spondylectomy and aortic repair surgery, and spinal cord ischemia occurs only in $0.3-1 \%$ of all strokes [3]. Spinal cord ischemia is also associated with thoracoabdominal aortic aneurysm [4]. Several potential mechanisms underlying these events have been identified, such as energy depletion, oxidative stress, and the activation of inflammatory pathways after spinal cord ischemia $[1,5-8]$.

The initial step in energy production from glucose is glycolysis. This process is controlled by phosphoglycerate mutase (PGAM) [E.C. 5.4.2.1], which catalyzes the interconversion of 2- and 3-phosphoglycerate $[9,10]$. In mammals, three isozymes $(\mathrm{mm}-, \mathrm{mb}-$, or bb-type) are present, classified based on the subunits of the PGAM dimer. Among these isozymes, mm- and bb-type isozymes are ubiquitously expressed in most tissues, including the brain, and $\mathrm{mm}$ - and mb-type isozymes are expressed in smooth, cardiac, and skeletal muscles. The brain form of PGAM (PGAM1) increases glycolysis in the brain and facilitates ATP production; however, oxidative modification inhibits glycolysis and, eventually, depletes ATP in the brain [11].

PGAM1 is overexpressed in several types of cancer cells in humans and is related to the growth, survival, and invasion of tumors [12]. In addition, PGAM1 can be a promising target for diagnosis and therapy in tumoral cells [12]. The ectopic expression of PGAM1 was shown to decrease senescence-induced oxidative damage in a primary mouse embryonic fibroblast cell line [13]. In fibroblasts, PGAM1 levels are increased under hypoxic conditions [14], and increased glycolysis is associated with protection against oxidative stress [15]. Most glycolytic genes are transcriptionally regulated by hypoxia-inducible factor-1 (HIF1), a principal regulator of the molecular response to hypoxia in addition to PGAM $[16,17]$.

Trans-activator of transcription (Tat), a protein transduction domain, was first discovered in human immunodeficiency virus- 1 and shows great efficacy in penetrating the cell membrane and blood-brain barrier $[18,19]$. In a previous study, we synthesized a Tat-PGAM1 fusion protein to cross the blood-brain barrier and deliver PGAM1 intracellularly [20]. We also demonstrated that PGAM1 increased the energy utilization in the hippocampus of gerbils to protect neurons from ischemic damage [21]. In addition, PGAM1 increased hippocampal neurogenesis and phosphorylated cAMP response element binding protein in the dentate gyrus [20].

In the present study, we investigated the effects of Tat-PGAM1 and its control protein (Control-PGAM1) against oxidative stress in the NSC34 cell line, which is a hybrid of mouse neuroblastoma cells and motor neurons from the spinal cord of mouse embryos [22]. We also examined the effects of Tat-PGAM1 and Control-PGAM1 in rabbits to determine their neuroprotective potential against spinal cord ischemia.

\section{Results}

\subsection{Tat-PGAM1, but Not Control-PGAM1, Was Effectively Delivered into NSC34 Cells}

Tat-PGAM1 and Control-PGAM1 delivery was assessed using a western blot for polyhistidine with a His-Tag inserted into the vector to visualize the intracellular delivery of proteins. Polyhistidine bands were not observed at any concentration $(0.5-5.0 \mu \mathrm{M})$ or time (15-60 $\mathrm{min}$ ) after Control-PGAM1 treatment. In contrast, incubation with $1.0 \mu \mathrm{M}$ Tat-PGAM1 significantly increased the polyhistidine levels in a concentration-dependent manner. In addition, incubation with $3.0 \mu \mathrm{M}$ Tat-PGAM1 significantly increased the polyhistidine levels in a time-dependent manner by $60 \mathrm{~min}$ after treatment.

Intracellular delivery of Tat-PGAM1 and Control-PGAM1 was visualized using immunocytochemical staining for polyhistidine $1 \mathrm{~h}$ after treatment with $3.0 \mu \mathrm{M}$ Tat-PGAM1 and Control-PGAM1. In the control and Control-PGAM1-treated groups, no polyhistidine immunoreaction was seen in NSC34 cells. In the Tat-PGAM1-treated group, strong polyhistidine immunoreactivity was found in the cytoplasm, but not in the nucleus, of NSC34 cells. In addition, polyhistidine immunoreactivity was significantly increased 
in the Tat-PGAM1-treated group compared to that in the control and Control-PGAM1-treated groups (Figure 1).
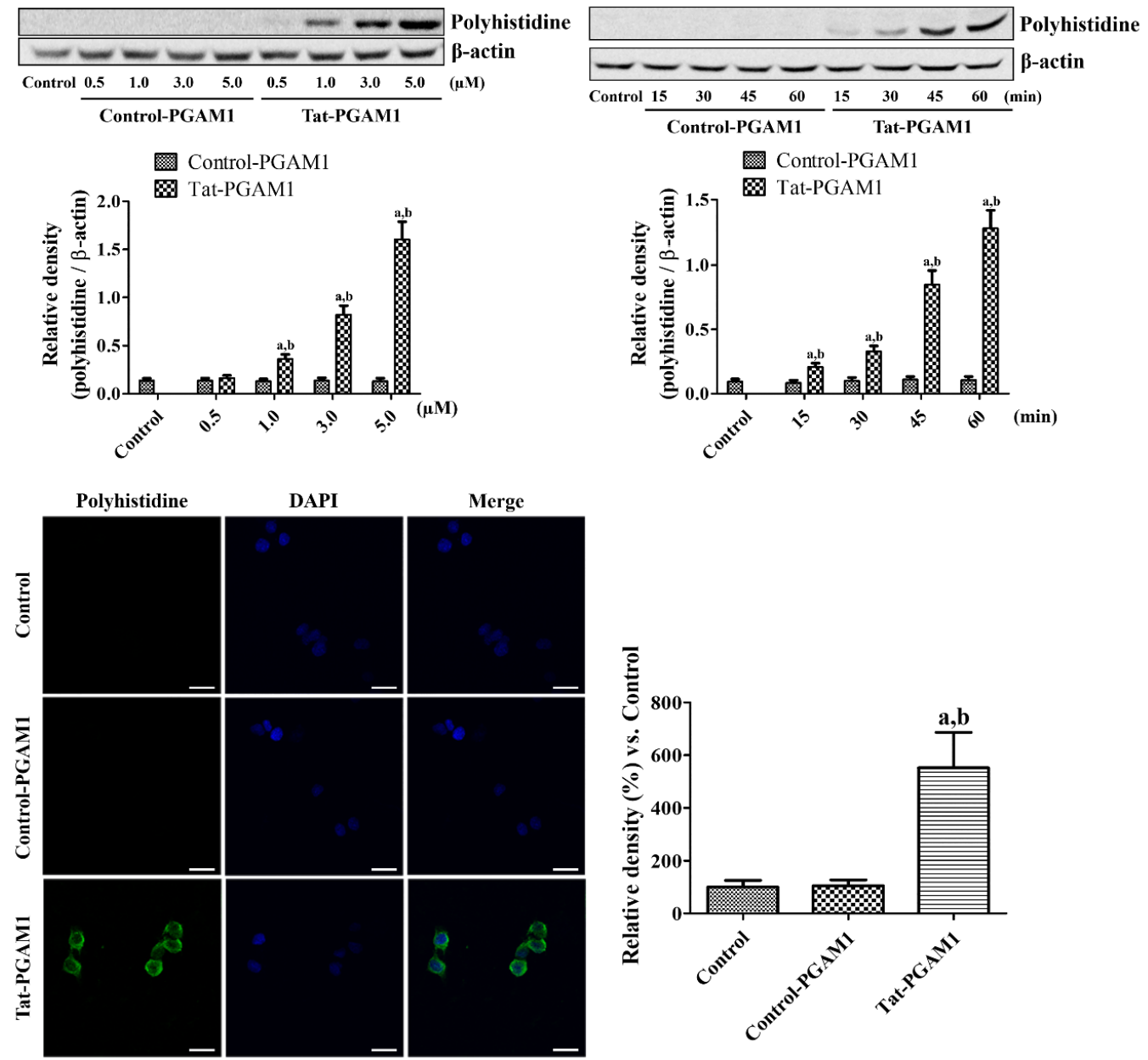

Figure 1. Intracellular delivery of Trans-activator of transcription-phosphoglycerate mutase 1 (Tat-PGAM1) and Control-PGAM1 into NSC34 cells. To assess the concentration dependence, NSC34 cells were incubated with various concentrations $(0.5-5.0 \mu \mathrm{M})$ of Tat-PGAM1 and Control-PGAM1 proteins for $1 \mathrm{~h}$. To assess the time dependence, NSC34 cells were incubated with $3 \mu \mathrm{M}$ each of Tat-PGAM1 and Control-PGAM1 for various durations (15-60 min). Delivery was confirmed by western blot analysis for polyhistidines. The delivery of Tat-PGAM1 and Control-PGAM1 was visualized by immunohistochemical staining for polyhistidine $60 \mathrm{~min}$ after protein (both $3 \mu \mathrm{M}$ ) incubation. Scale bar $=50 \mu \mathrm{m}$. The optical densities of the polyhistidine bands and immunoreactivities were measured and the data were analyzed using two-way ANOVA followed by Bonferroni's post hoc test ( ${ }^{\mathrm{a}} p<0.05$, significantly different from the control group; ${ }^{\mathrm{b}} p<0.05$, significantly different from the Control-PGAM1 group). The bar graph represents the mean \pm standard deviation (SD).

\subsection{Tat-PGAM1, but Not Control-PGAM1, Protects NSC34 Cells from Oxidative Damage}

The cell viability and DNA fragmentation were measured using the water-soluble tetrazolium salt-1 (WST-1) assay and terminal deoxynucleotidyl transferase-mediated biotinylated deoxyuridine triphosphate (dUTP) nick end labeling (TUNEL) staining. Incubation with $1 \mathrm{mM} \mathrm{H}_{2} \mathrm{O}_{2}$ for $5 \mathrm{~h}$ dramatically decreased the cell viability to $50.9 \%$ of the control group. Pre-incubation with $0.5-5.0 \mu \mathrm{M}$ Control-PGAM1 for $1 \mathrm{~h}$ and subsequent treatment with $1 \mathrm{mM} \mathrm{H}_{2} \mathrm{O}_{2}$ for $5 \mathrm{~h}$ had no significant effects on the cell viability at any concentration. However, incubation with Tat-PGAM1 increased the cell viability in a concentration-dependent manner; the cell viability was significantly increased in the $3.0 \mu \mathrm{M}$ and $5.0 \mu \mathrm{M}$ Tat-PGAM1-treated groups as compared to the only $\mathrm{H}_{2} \mathrm{O}_{2}$ group or the concentration-matched 
Control-PGAM1-treated group. In the $3.0 \mu \mathrm{M}$ and $5.0 \mu \mathrm{M}$ Tat-PGAM1-treated groups, cell viability was $70.7 \%$ and $77.6 \%$ of the control group, respectively (Figure 2).
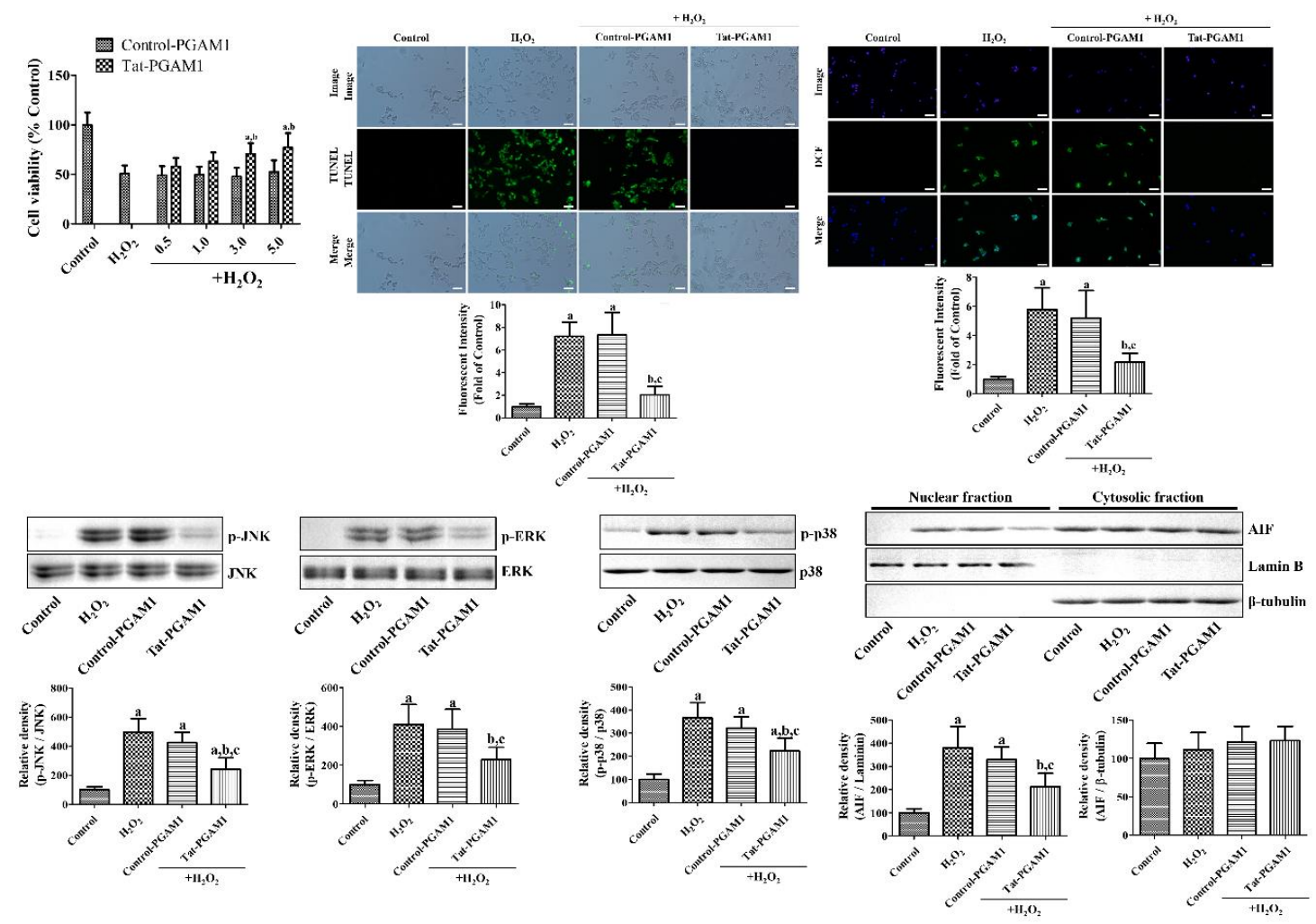

Figure 2. The protective effects of Tat-PGAM1 and Control-PGAM1 against oxidative damage in NSC34 cells. Oxidative stress was induced by treatment with $1 \mathrm{mM} \mathrm{H}_{2} \mathrm{O}_{2}$ for $3 \mathrm{~h}$ (terminal deoxynucleotidyl transferase-mediated biotinylated deoxyuridine triphosphate (dUTP) nick end labeling (TUNEL) staining), $5 \mathrm{~h}$ (water-soluble tetrazolium salt-1 (WST-1) assay), $10 \mathrm{~min}$ (2,7-dichlorofluorescein (DCF) fluorescence), or $6 \mathrm{~h}$ (western blot). The cells were incubated with Tat-PGAM1 and Control-PGAM1 (both $3 \mu \mathrm{M}$ for TUNEL and DCF staining) for $60 \mathrm{~min}$ before treatment with $1 \mathrm{mM} \mathrm{H}_{2} \mathrm{O}_{2}$ and measured with each assay kit. The cell viability, DNA fragmentation, and reactive oxygen species (ROS) formation were measured using a WST-1 assay, TUNEL staining, and DCF fluorescence, respectively. Scale bar $=50 \mu \mathrm{m}$. Mitogen-activated protein kinase (MAPK) pathways were confirmed by western blot analysis for c-jun N-terminal kinase (JNK), extracellular-signal-regulated kinase (ERK), p38, and their phosphorylated antibodies. In addition, apoptosis inducing factor (AIF) levels were measured in nuclear and cytosolic fraction. The cell viability was measured and the data were analyzed using two-way ANOVA followed by Bonferroni's post hoc test ( ${ }^{\mathrm{a}} \mathrm{p}<0.05$, significantly different from the control group; and ${ }^{\mathrm{b}} p<0.05$, significantly different from the Control-PGAM1 group). The intensities of TUNEL positive cells, the DCF fluorescence, and the optical densities of the protein bands were measured and the data were analyzed using one-way ANOVA followed by Bonferroni's post hoc test ( ${ }^{\mathrm{a}} p<0.05$, significantly different from the control group; ${ }^{\mathrm{b}} p<0.05$, significantly different from the only $\mathrm{H}_{2} \mathrm{O}_{2}$ group; and ${ }^{\mathrm{c}} p<0.05$, significantly different from the Control-PGAM1 group). The bar graph represents the mean \pm standard deviation (SD).

In the control group, few TUNEL-positive cells were found in the NSC34 cell lines. Incubation with $1 \mathrm{mM} \mathrm{H} \mathrm{O}_{2}$ for $3 \mathrm{~h}$ showed several TUNEL-positive structures in the NSC34 cell line, and the fluorescence intensity was significantly higher (578.5\%) in the control group. Pre-incubation with 3.0 $\mathrm{\mu M}$ Control-PGAM1 for $1 \mathrm{~h}$ and subsequent treatment with $1 \mathrm{mM} \mathrm{H}_{2} \mathrm{O}_{2}$ for $3 \mathrm{~h}$ showed several TUNEL-positive structures in NSC34 cells, and the fluorescence intensity was similar to the $\mathrm{H}_{2} \mathrm{O}_{2}$ alone group. Pre-incubation with $3.0 \mu \mathrm{M}$ Tat-PGAM1 for $1 \mathrm{~h}$ and subsequent treatment with $1 \mathrm{mM}$ 
$\mathrm{H}_{2} \mathrm{O}_{2}$ for $3 \mathrm{~h}$ dramatically decreased TUNEL-positive structures in NSC34 cells as compared to the $\mathrm{H}_{2} \mathrm{O}_{2}$ alone group, and the fluorescence intensity was $62.6 \%$ less than the $\mathrm{H}_{2} \mathrm{O}_{2}$ alone group, and $216.5 \%$ of the control group (Figure 2).

To elucidate the antioxidant effects of Tat-PGAM1 against $\mathrm{H}_{2} \mathrm{O}_{2}$-induced oxidative damage, the reactive oxygen species (ROS) levels were measured based on the 2,7-dichlorofluorescein (DCF) formation in NSC34 cells. In the control group, the DCF fluorescence levels in the NSC34 cells were very low; however, incubation with $1 \mathrm{mM} \mathrm{H}_{2} \mathrm{O}_{2}$ for $10 \mathrm{~min}$ and $20 \mu \mathrm{M}$ DCF diacetate (DCF-DA) for 30 min significantly increased the DCF formation in NSC34 cells, and the fluorescence intensity was significantly increased to $721.9 \%$ of that of the control group. Sequential incubation with $3.0 \mu \mathrm{M}$ Control-PGAM1 for $1 \mathrm{~h}, 1 \mathrm{mM} \mathrm{H}_{2} \mathrm{O}_{2}$ for $10 \mathrm{~min}$, and $20 \mu \mathrm{M}$ DCF-DA for $30 \mathrm{~min}$ showed abundant DCF formation in NSC34 cells. The DCF fluorescence intensity was similar to that of the $\mathrm{H}_{2} \mathrm{O}_{2}$ alone group. However, sequential incubation with $3.0 \mu \mathrm{M}$ Tat-PGAM1 for $1 \mathrm{~h}, 1 \mathrm{mM} \mathrm{H}_{2} \mathrm{O}_{2}$ for $10 \mathrm{~min}$, and $20 \mu \mathrm{M}$ DCF-DA for 30 min significantly decreased the DCF formation in NSC34 cells as compared to the $\mathrm{H}_{2} \mathrm{O}_{2}$ alone group. In this group, the DCF fluorescence intensity was $71.6 \%$ less than the $\mathrm{H}_{2} \mathrm{O}_{2}$ alone group, and $205.0 \%$ of the control group (Figure 2).

The signal transduction mechanisms were assessed using western blot analysis for mitogen-activated protein kinases (MAPKs), such as c-Jun N-terminal kinase (JNK), extracellular-signal-regulated kinase (ERK), p38, and their phosphorylated forms (p-JNK, p-ERK, and p-p38, respectively). The levels of JNK, ERK, and p38 did not show any significant differences among groups. However, incubation with $1 \mathrm{mM} \mathrm{H}_{2} \mathrm{O}_{2}$ for $6 \mathrm{~h}$ showed significant increases of the p-JNK (497.0\%), p-ERK (409.9\%), and p-p38 (366.1\%) protein levels compared to their control groups in NSC34 cells. Pre-incubation with $3.0 \mu \mathrm{M}$ Control-PGAM1 for $1 \mathrm{~h}$ and subsequent treatment with $1 \mathrm{mM} \mathrm{H}_{2} \mathrm{O}_{2}$ for $6 \mathrm{~h}$ showed similar increases of the p-JNK, p-ERK, and p-p38 protein levels in the protein compared to those in control group, respectively. Pre-incubation with $3.0 \mu \mathrm{M}$ Tat-PGAM1 for $1 \mathrm{~h}$ and subsequent treatment with $1 \mathrm{mM} \mathrm{H}_{2} \mathrm{O}_{2}$ for $6 \mathrm{~h}$ significantly decreased p-JNK ( $51.7 \%$ less than the $\mathrm{H}_{2} \mathrm{O}_{2}$ alone group, $240.1 \%$ of control), p-ERK ( $44.3 \%$ less than the $\mathrm{H}_{2} \mathrm{O}_{2}$ alone group, 228.5\% of control), and p-p38 (39.0\% less than the $\mathrm{H}_{2} \mathrm{O}_{2}$ alone group, $223.4 \%$ of the control) protein levels in NSC34 cells compared to those in Tat peptide treated group (Figure 2).

Apoptosis inducing factor (AIF) was also measured by western blot analysis in cytosolic and nuclear fractions of NSC34 cells. Incubation with $1 \mathrm{mM} \mathrm{H}_{2} \mathrm{O}_{2}$ for $6 \mathrm{~h}$ significantly increased AIF levels in the nuclear fraction by $379.9 \%$ of control group. Pre-incubation with $3.0 \mu \mathrm{M}$ Tat-PGAM1, not Control-PGAM1, showed significantly lower levels of AIF (44.2\% less than the $\mathrm{H}_{2} \mathrm{O}_{2}$ alone group, $212.1 \%$ of the control) in nuclear fraction than the $\mathrm{H}_{2} \mathrm{O}_{2}$ alone group. However, in the cytosolic fraction, the AIF levels did not show any significant differences among groups (Figure 2).

\subsection{Tat-PGAM1, but Not Control-PGAM1, Prevents Neuronal Damage in the Ventral Horn of the Rabbit Spinal Cord}

In the control uninjured group, the rabbits did not show any significant changes in the partial pressure of oxygen $\left(\mathrm{PaO}_{2}\right)$, partial pressure of carbon dioxide $\left(\mathrm{PaCO}_{2}\right), \mathrm{pH}$, and glucose before and $10 \mathrm{~min}$ after reperfusion (Table 1). Neurological changes induced by spinal cord ischemia were assessed by Tarlov's neurological scores at 24 and $72 \mathrm{~h}$ after ischemia. In the control group, rabbits did not show any significant changes in their neurological scores at 24 or $72 \mathrm{~h}$ after ischemia, whereas in the Tat peptide-treated group, the neurological scores were significantly decreased when compared with the control group; they were 0.9 and 1.2 at 24 and $72 \mathrm{~h}$ after ischemia, respectively. In the Control-PGAM1-treated group, the neurological scores were similar to those of the Tat peptide treated group at 24 and $72 \mathrm{~h}$ after ischemia. The Tat-PGAM1-treated group showed significantly higher neurological scores than the Tat peptide- or Control-PGAM1-treated groups at 24 and $72 \mathrm{~h}$ after ischemia (Figure 3). 
Table 1. The physiological parameters before and $10 \mathrm{~min}$ after spinal cord ischemia in rabbits.

\begin{tabular}{lccccc}
\hline & $\mathbf{p H}$ & $\begin{array}{c}\text { Distal Mean } \\
\text { Arterial Pressure } \\
\text { (MAP) }(\mathbf{m m H g})\end{array}$ & $\mathbf{P a C O}_{2}(\mathbf{m m H g})$ & $\mathbf{P a O}_{2}(\mathbf{m m H g})$ & Glucose (mM) \\
\hline Pre-ischemia & & & & \\
\hline Control & $7.39 \pm 0.027$ & $83.8 \pm 9.14$ & $37.2 \pm 4.13$ & $104.6 \pm 9.15$ & $6.43 \pm 0.98$ \\
\hline Vehicle & $7.42 \pm 0.033$ & $84.2 \pm 8.81$ & $36.9 \pm 3.80$ & $103.5 \pm 8.72$ & $6.52 \pm 1.29$ \\
\hline Control-PGAM1 & $7.41 \pm 0.035$ & $84.1 \pm 9.42$ & $37.1 \pm 3.75$ & $106.4 \pm 11.3$ & $6.38 \pm 0.81$ \\
\hline Tat-PGAM1 & $7.39 \pm 0.032$ & $84.0 \pm 8.06$ & $36.8 \pm 4.37$ & $103.9 \pm 10.4$ & $6.41 \pm 1.05$ \\
\hline Reperfusion 10 min & & & & \\
\hline Control & $7.41 \pm 0.032$ & $84.1 \pm 8.60$ & $37.0 \pm 4.42$ & $103.7 \pm 9.71$ & $6.37 \pm 1.08$ \\
\hline Vehicle & $7.35 \pm 0.068$ & $88.7 \pm 11.3$ & $39.3 \pm 5.95$ & $111.4 \pm 11.9$ & $7.10 \pm 1.42$ \\
\hline Control-PGAM1 & $7.36 \pm 0.092$ & $87.8 \pm 10.2$ & $39.7 \pm 5.28$ & $106.6 \pm 12.7$ & $6.83 \pm 1.27$ \\
\hline Tat-PGAM1 & $7.37 \pm 0.088$ & $86.3 \pm 9.92$ & $38.1 \pm 5.60$ & $114.1 \pm 11.1$ & $7.25 \pm 1.62$ \\
\hline
\end{tabular}

Transient spinal cord ischemia had no significant effects on physiological parameters in the control, vehicle-treated, Control-PGAM1-treated, and Tat-PGAM1-treated groups.

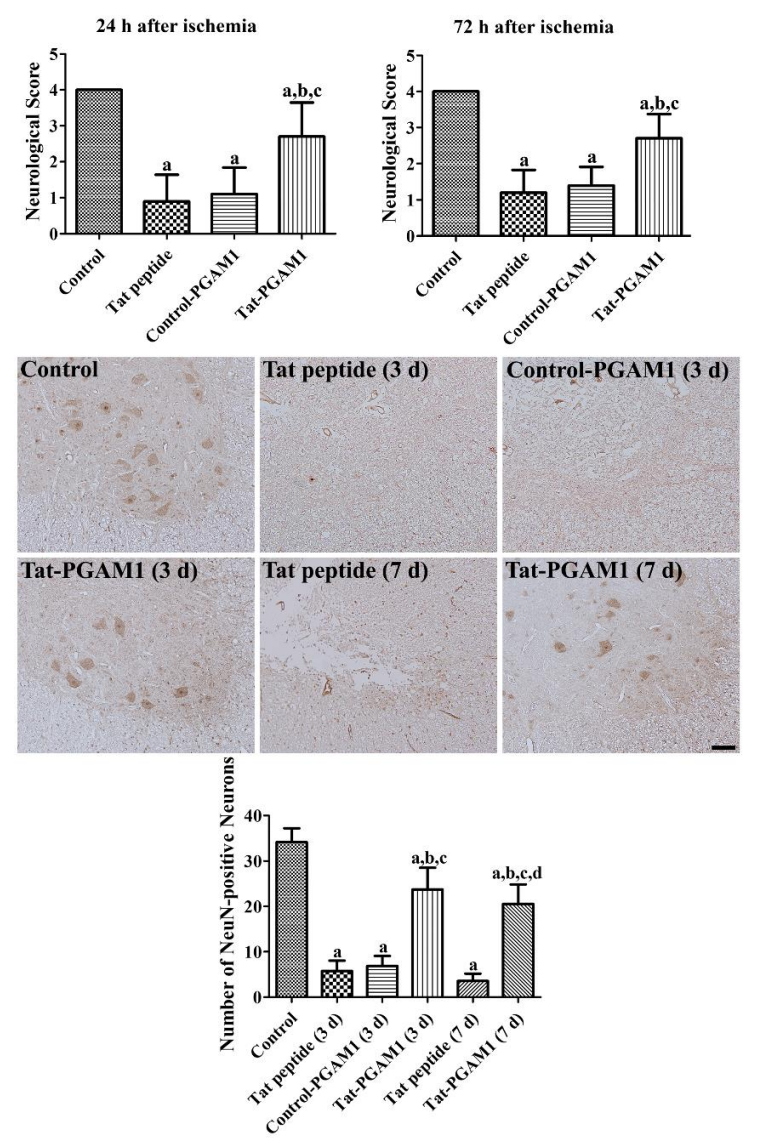

Figure 3. The protective effects of Tat-PGAM1 and Control-PGAM1 against ischemic damage in the rabbit spinal cord. Neurological scores of the control, Tat peptide-, Control-PGAM1-, and Tat-PGAM1-treated groups were measured using the modified Tarlov's criteria at 24 and $72 \mathrm{~h}$ after ischemia/reperfusion. The animals were sacrificed 3 days or 7 days after ischemia for NeuN immunohistochemical staining in the lumbar segments $\left(\mathrm{L}_{6}-\mathrm{L}_{7}\right)$ of the spinal cord. Scale bar $=100 \mu \mathrm{m}$. The number of NeuN-positive cells were counted in the spinal cord per section for all the groups, and the data were analyzed using one-way ANOVA followed by Bonferroni's post hoc test ( ${ }^{\mathrm{a}} p<0.05$, significantly different from the control group; ${ }^{\mathrm{b}} p<0.05$, significantly different from the Tat peptide ( $\left.3 \mathrm{~d}\right)$ group; ${ }^{\mathrm{c}} p<0.05$, significantly different from the Control-PGAM1 ( $3 \mathrm{~d}$ ) group; and ${ }^{\mathrm{d}} p<0.05$, significantly different from the Tat peptide ( $\mathrm{d}$ ) group). Th bar graph represents the mean \pm standard deviation (SD). 
Neuronal damage was evaluated using neuronal nuclei (NeuN) immunohistochemical staining in the ventral horn of the spinal cord. In the control group, abundant NeuN-positive neurons were found in the spinal cord. In the Tat peptide- and Control-PGAM1-treated groups, a few NeuN-positive cells were observed in the ventral horn of the spinal cord, and this number was significantly decreased to $9.5 \%$ and $12.3 \%$ of the control group, respectively, 3 days after ischemia. In the Tat-PGAM1-treated group, some neurons were immunostained with $\mathrm{NeuN}$, and this number was significantly increased to $65.0 \%$ of the control group when compared with the Tat peptide- and Control-PGAM1-treated groups 3 days after ischemia. Seven days after ischemia, fewer NeuN-positive cells were found in the Tat-peptide- ( $8.4 \%$ of control) or Tat-PGAM1-treated ( $57.1 \%$ of control) groups compared to those in 3 days post-ischemic groups. However, the number of NeuN-positive neurons were significantly higher in the Tat-PGAM1-treated group than that in the Tat-peptide-treated group (Figure 3).

\subsection{Tat-PGAM1, but Not Control-PGAM1, Reduces Inflammatory Responses and Oxidative Damage after Ischemia}

The inflammatory responses were evaluated using immunohistochemical staining for ionized calcium-binding adapter protein-1 (Iba-1) and enzyme-linked immunosorbent assay (ELISA) for interleukin (IL)-1 $\beta$, IL-6, and tumor necrosis factor (TNF)- $\alpha$. In the control group, Iba-1-immunoreactive microglia had low proportions of cytoplasm and long processes in the ventral horn of the spinal cord (inset image). In the Tat peptide-treated group, we observed numerous Iba-1-immunoreactive microglia with hypertrophied and round cytoplasm (phagocytic form, see the inset image).

In this group, the Iba- 1 immunoreactivity was significantly increased to $458.1 \%$ of the control group. In the Control-PGAM1-treated group, the Iba-1 immunoreactive microglia showed similar morphology, and the Iba-1 immunoreactivity was similar to that of the Tat peptide-treated group. In the Tat-PGAM1-treated group, the Iba-1 immunoreactive microglia had hypertrophied cytoplasm with retracted processes (activated form, inset image); however, phagocytic forms were rarely observed in the spinal cord. In this group, the Iba-1 immunoreactivity was significantly decreased compared to the Tat peptide- and Control-PGAM1-treated groups. The IL-1 $\beta$ in the Tat peptide- and Control-PGAM1-treated groups transiently increased at $24 \mathrm{~h}$ after ischemia and decreased $72 \mathrm{~h}$ after ischemia, when compared to the basal level. In the Tat-PGAM1-treated group, the IL-1 $\beta$ levels were significantly lower at $24 \mathrm{~h}$ and higher at $72 \mathrm{~h}$ after ischemia. Unlike IL-1 $\beta$, the IL- 6 and TNF- $\alpha$ levels in all groups gradually increased at $24 \mathrm{~h}$ and decreased at $72 \mathrm{~h}$ after ischemia. In the Tat-PGAM1-treated group, the IL-6 levels were significantly lower at 24 and $72 \mathrm{~h}$ after ischemia when compared to the time-matched Tat-peptideand Control-PGAM1-treated groups. In addition, the TNF- $\alpha$ levels were significantly lower in the Tat-PGAM1-treated group than in the Tat-peptide- and Control-PGAM1-treated groups after ischemia.

The oxidative damage was assessed by measuring the malondialdehyde (MDA) and 8-iso-prostaglandin F2 $\alpha$ (8-iso-PGF2 $\alpha$ ) levels generated from the membrane at 8,24 , and $72 \mathrm{~h}$ after ischemia. In all groups, the MDA and 8-iso-PGF2 $\alpha$ levels increased in a time-dependent manner in the spinal cord after ischemia. However, in the Tat-PGAM1-treated group, the MDA and 8-iso-PGF2 $\alpha$ levels were significantly lower at 8,24 , and $72 \mathrm{~h}$ after ischemia compared to the time-matched Tat peptide- and Control-PGAM1-treated groups (Figure 4). 


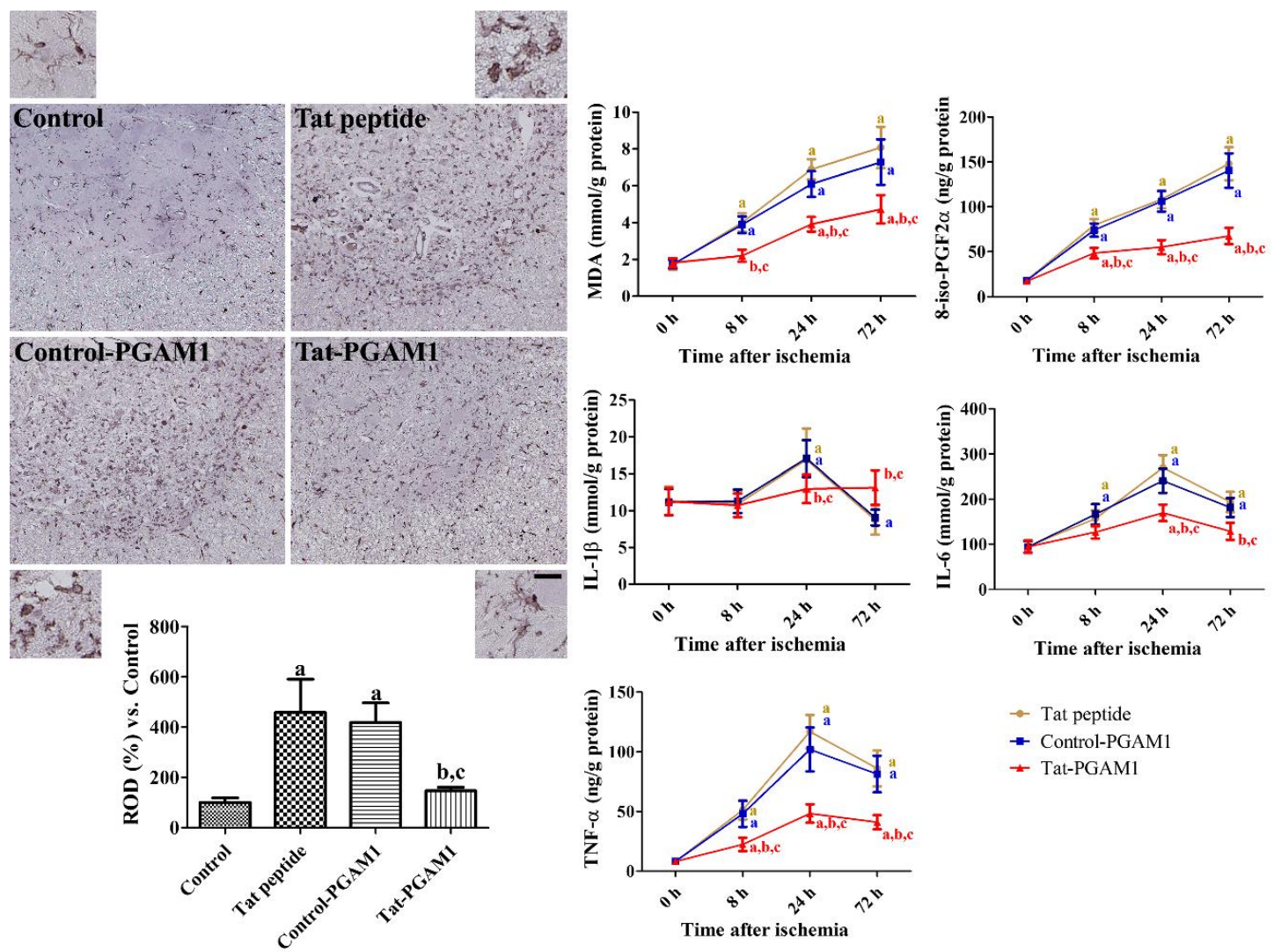

Figure 4. The anti-oxidative and anti-inflammatory effects of Tat-PGAM1 and Control-PGAM1 against ischemic damage in the rabbit spinal cord. Iba- 1 immunohistochemistry was conducted to visualize the morphology of microglia/macrophages in the ventral horn of the spinal cord. Scale bar $=100 \mu \mathrm{m}, 25 \mu \mathrm{m}$ (inset image). The relative optical densities were expressed as percentile values of Iba- 1 immunoreactivity versus control group per section. The lipid peroxidation and oxidized arachidonic acid were determined by MDA and 8-iso-PGF2 $\alpha$ assay, respectively, after ischemia/reperfusion. In addition, pro-inflammatory cytokines, such as Interleukin (IL)-1 $\beta$, IL-6, and tumor necrosis factor (TNF)- $\alpha$ were measured in the spinal cord after ischemia/reperfusion. The data were analyzed using one- or two-way ANOVA followed by Bonferroni's post hoc test ( ${ }^{\mathrm{a}} p<0.05$, significantly different from the control group; $\mathrm{b}_{p}<0.05$, significantly different from the Tat peptide group; and ${ }^{\mathrm{c}} p<0.05$, significantly different from the Control-PGAM1 group). The bar graph represents the mean \pm standard deviation (SD).

\section{Discussion}

PGAM is an enzyme in the glycolytic pathway that catalyzes the interconversion of 2- and 3-phosphoglycerate [10]. PGAM1 is highly susceptible to oxidative stress, which leads to the inhibition of glycolysis and is easily oxidized in conditions of neurological disease, such as Alzheimer's disease and hypoxic damage [23-25]. In addition, PGAM1 levels are decreased in the brains of mice models of phenylketonuria [26] and in the hippocampus of mice exposed to copper toxicity [27]. In the present study, we synthesized a Tat-PGAM1 fusion protein, which easily crosses the blood-brain barrier and cell membrane, to elucidate its role in protecting against oxidative and ischemic damage in NSC34 cells and the rabbit spinal cord. We confirmed the intracellular delivery of the Tat-PGAM1 fusion protein into motor neuron-like cells, such as NSC34 cells in a concentration- and time-dependent manner. This result is consistent with a previous study showing that Tat-PGAM1 can be effectively delivered to hippocampal cell lines [21]. In addition, we observed the treatment with Tat-PGAM1 significantly reduced the neurological deficits induced by spinal cord ischemia 24 and $72 \mathrm{~h}$ after ischemia. NeuN immunohistochemistry releveled that Tat-PGAM1 protected neurons from ischemic damage in the spinal cord $72 \mathrm{~h}$ after ischemia, and we confirmed that this effect was maintained by 7 days 
after ischemia. We also observed that Tat-PGAM1, and not Control-PGAM1, protected neurons from oxidative damage; NSC34 cells incubated with $1 \mathrm{mM} \mathrm{H}_{2} \mathrm{O}_{2}$ showed reduced DNA fragmentation and ROS formation when treated with Tat-PGAM1.

$\mathrm{H}_{2} \mathrm{O}_{2}$ produced by oxidative stress activates MAPK $[28,29]$, and the treatment with MAPK pathway inhibitor reduces neuronal damage in neural cells induced by $\mathrm{H}_{2} \mathrm{O}_{2}$ [30]. In the present study, we observed that $1 \mathrm{mM} \mathrm{H}_{2} \mathrm{O}_{2}$ significantly increased the phosphorylation of JNK, ERK, and p38 in NSC34 cells, and the treatment with Tat-PGAM1, not Control-PGAM1, significantly ameliorated the increases of MAPK phosphorylation in NSC34 cells exposed to $\mathrm{H}_{2} \mathrm{O}_{2}$. This result suggests that Tat-PGAM1 ameliorates the $\mathrm{H}_{2} \mathrm{O}_{2}$-induced activation of MAPKs, such as JNK, ERK, and p38 in the NSC34 cells.

We also observed the nuclear fraction of AIF in NSC34 cells after exposure to $\mathrm{H}_{2} \mathrm{O}_{2}$ because the translocation of AIF into nucleus occurred in the cell death pathway [31]. Exposure to $\mathrm{H}_{2} \mathrm{O}_{2}$ significantly increased the nuclear AIF levels, and the treatment with Tat-PGAM1 ameliorated the translocation of AIF, indicating the protective potentials of Tat-PGAM1. This result is supported by previous studies that showed that enhanced glycolytic flux decreased cellular senescence by reducing oxidative damage [13,32].

In addition, we examined MDA and 8-iso-PGF2 $\alpha$, which are indicators of the oxidative status [33]. Spinal cord ischemia significantly increased the MDA and 8-iso-PGF2 $\alpha$ levels in the spinal cord, and these results are consistent with previous studies that showed that spinal cord ischemia increased biomarkers of free radical damage $[5,8,34]$. Treatment with Tat-PGAM1, and not Control-PGAM1, significantly ameliorated the increase in MDA and 8-iso-PGF2 $\alpha$ levels in the spinal cord. These results suggest that Control-PGAM1 could not cross the blood-brain barrier or cell membrane in the spinal cord and that Tat-PGAM1 reduces lipid peroxidation and oxidized arachidonic acid products induced by ROS after spinal cord ischemia. PGAM1 is known to reduce oxidative stress by inactivation of nicotinamide adenine dinucleotide phosphate under hypoxic conditions [35].

Neuroinflammation is closely related to the energy metabolism. Pro-inflammatory macrophages receive energy from glycolysis, whereas anti-inflammatory macrophages rely on oxidative phosphorylation for their function [36-38]. In the present study, we observed Iba-1-immunoreactive microglia and pro-inflammatory cytokine levels in the spinal cord because pro-inflammatory cytokines are known to play important roles in hyperalgesia and the death of neuronal and glial cells in association with secondary spinal cord injuries [39-43]. Transient forebrain ischemia significantly changes the morphology of Iba-1-immunoreactive microglia, increasing the proportion of phagocytic microglia to remove cells that died due to ischemia damage [44]. Treatment with Tat-PGAM1 significantly reduced the phagocytic form of microglia, indicating reduced inflammatory responses in the spinal cord after ischemia as compared to the Tat peptide- and Control-PGAM1-treated groups.

Several studies have demonstrated glial activation and crosstalk with pro-inflammatory cytokines $[27,45]$ to reduce the propagation of damage after ischemia. In the present study, we observed transient increases in pro-inflammatory cytokines, such as IL-1 $\beta$, IL-6, and TNF- $\alpha$ in the spinal cord after ischemia, indicating inflammation. TNF- $\alpha$ and IL-1 $\beta$ levels increase after spinal cord injury [7] and biphasically peak at 6 and 36-48 h after ischemia/reperfusion [6]. However, IL-6 is transiently increased and returns to basal levels 4 days after ischemia [46,47]. Treatment with Tat-PGAM1 significantly alleviated the transient increases in pro-inflammatory cytokines after ischemia and reduced the inflammatory response. However, in immature murine articular chondrocytes, transfection of PGAM1 increased IL-1 $\beta$, IL-6, and TNF- $\alpha$ transcription levels in a concentration-dependent manner [48]. This contradictory result may be associated with specific conditions in the animal model and target organs. In the present study, we compared IL-1 $\beta$, IL- 6 , and TNF- $\alpha$ levels in the spinal cord after ischemia, whereas Song et al. measured cytokine levels in immature articular chondrocytes under normal conditions [48].

Collectively, our study investigated the effects of Tat-PGAM1 on $\mathrm{H}_{2} \mathrm{O}_{2}$-induced oxidative stress in NSC34 cells and ischemia-induced cell damage. Tat-PGAM1 lowers the ROS formation, 
MAPK activation, and nuclear translocation of AIF in NSC34 cells and membrane peroxidation in the spinal cord. In addition, Tat-PGAM1 reduces the microglial activation and subsequent increases in pro-inflammatory cytokines after ischemia. These results suggest that Tat-PGAM1 could reduce the complications induced by ischemic damage in the rabbit spinal cord.

\section{Materials and Methods}

\subsection{Concentration- and Time-Dependent Delivery of Tat-PGAM1 into NSC34 Cells}

As described in a previous study [20], Tat-PGAM1 and Control-PGAM1 proteins were generated with and without Tat, respectively, based on a human PGAM1 CDNA clone in a TA vector. To differentiate intracellular PGAM1 from exogenous Tat-PGAM1 and Control-PGAM1, a His-tag was inserted into the vector system. Tat-PGAM1 or Control-PGAM1 plasmids were transformed into Escherichia coli BL21 cells, cultivated in broth media, and purified using a $\mathrm{Ni}^{2+}$-nitrilotriacetic acid Sepharose affinity column (Qiagen, Chatsworth, CA, USA) and PD-10 column chromatography (GE Healthcare, Chicago, IL, USA).

Concentration- and time-dependent delivery of Tat-PGAM1 and Control-PGAM1 was observed using western blotting for polyhistidines. Briefly, NSC34 cells were exposed to various concentrations $(0.5-5.0 \mu \mathrm{M})$ of Tat-PGAM1 or Control-PGAM1 protein for $60 \mathrm{~min}$ or to $3 \mu \mathrm{M}$ protein for various periods (15-60 $\mathrm{min})$.

\subsection{Visualization of Intracellular Delivery of Tat-PGAM1 in NSC34 Cells}

The intracellular delivery of Tat-PGAM1 and Control-PGAM1 was visualized using immunocytochemical staining for polyhistidine. Briefly, coverslip-grown NSC34 cells were exposed to $3 \mu \mathrm{M}$ Tat-PGAM1 or Control-PGAM1 protein for $60 \mathrm{~min}$ and the cells were fixed with $4 \%$ paraformaldehyde (PFA) in $0.1 \mathrm{M}$ phosphate buffer (PB, pH 7.4) for 5 min at $25^{\circ} \mathrm{C}$. Thereafter, the cells were sequentially incubated with mouse anti-polyhistidine antibody (Sigma, St. Louis, MO, USA) and Alexa Fluor ${ }^{\circledR} 488$-conjugated anti-mouse Immunoglobulin G (1:1000; Jackson ImmunoResearch, West Grove, PA, USA) with $1 \mu \mathrm{g} / \mathrm{mL}$ 4,6-diamidino-2-phenylindole (DAPI; Thermo Fisher Scientific, Waltham, MA, USA). The immunoreaction was observed under a confocal fluorescence microscope (LSM 510 META NLO; Zeiss GmbH, Jena, Germany) and the fluorescence was measured using a Fluoroskan ELISA plate reader (Labsystems Oy, Helsinki, Finland) at $485 \mathrm{~nm}$ excitation and $538 \mathrm{~nm}$ emission.

\subsection{Neuroprotective Effects of Tat-PGAM1 against Oxidative Damage in NSC34 Cells}

Oxidative stress in NSC34 cells was induced by treatment with $1 \mathrm{mM} \mathrm{H}_{2} \mathrm{O}_{2}$, and the neuroprotective effects of Tat-PGAM1 and Control-PGAM1 were assessed using WST-1 and TUNEL assays, as described in a previous study [49]. Briefly, various concentrations $(0.5-5.0 \mu \mathrm{M})$ or $3.0 \mu \mathrm{M}$ of Tat-PGAM1 and Control-PGAM1 were added to NSC34 cells for $60 \mathrm{~min}$, followed by $1 \mathrm{mM} \mathrm{H}_{2} \mathrm{O}_{2}$, and then incubated for $3 \mathrm{~h}$ or $5 \mathrm{~h}$ for TUNEL and WST-1 assays, respectively. The TUNEL staining and WST-1 assay were conducted as per the manufacturer instructions. The cell viability was assessed using the WST-1 assay, by measuring optical density at $450 \mathrm{~nm}$ using an ELISA microplate reader (Labsystems Multiskan MCC/340, Helsinki, Finland). DNA fragmentation by TUNEL staining was visualized using a fluorescence microscope (Nikon Eclipse 80i, Tokyo, Japan) and fluorescence was measured using a Fluoroskan ELISA plate reader (Labsystems Oy) at $485 \mathrm{~nm}$ excitation and $538 \mathrm{~nm}$ emission.

The intracellular ROS levels were visualized by monitoring the DCF formation from DCF-DA as described previously [8,49]. Briefly, $3.0 \mu \mathrm{M}$ of Tat-PGAM1 and Control-PGAM1 were added to NSC34 cells for $60 \mathrm{~min}$, followed by $1 \mathrm{mM} \mathrm{H}_{2} \mathrm{O}_{2}$, and then incubated for $10 \mathrm{~min}$. The cells were incubated with $20 \mu \mathrm{M}$ DCF-DA for $30 \mathrm{~min}$, and the fluorescence levels were measured using a Fluoroskan ELISA plate reader (Labsystems Oy) at $485 \mathrm{~nm}$ excitation and $538 \mathrm{~nm}$ emission.

The MAPK and AIF levels were assessed by western blot analysis using antibodies for JNK (1:500, Cell Signaling Technology, Inc., Beverly, MA, USA), ERK (1:500, Cell Signaling Technology, 
Inc.), p38 (1:1000, Cell Signaling Technology, Inc.), p-JNK (1:200, Cell Signaling Technology, Inc.), p-ERK (1:200, Cell Signaling Technology, Inc.), p-p38 (1:500, Cell Signaling Technology, Inc.), AIF (1:200, Cell Signaling Technology, Inc.), Laminin (1:1000, SantaCruz Biotechnology, Santa Cruz, CA, USA), and $\beta$-tubulin (1:1000, SantaCruz Biotechnology). Briefly, $3.0 \mu \mathrm{M}$ of Tat-PGAM1 and Control-PGAM1 were added to NSC34 cells for $60 \mathrm{~min}$, followed by $1 \mathrm{mM} \mathrm{H}_{2} \mathrm{O}_{2}$, followed by $1 \mathrm{mM}$ $\mathrm{H}_{2} \mathrm{O}_{2}$, and then incubated for $6 \mathrm{~h}$.

\subsection{Neuroprotective Effects of Tat-PGAM1 against Ischemic Damage in Rabbits}

Male New Zealand white rabbits $(1.2-1.5 \mathrm{~kg}$ ) were used in the study. Animals were supplied by DooYeol Biotech (Seoul, Korea). The experimental protocol was approved by the Institutional Animal Care and Use Committee (IACUC) of Seoul National University (approval number: SNU-191017-21). Animals were anesthetized with 2.5\% isoflurane (Hana Pharm Co., Ltd., Hwaseong, Korea) with a mixture of $67 \% \mathrm{~N}_{2} \mathrm{O}$ and $33 \% \mathrm{O}_{2}$ gas. A midline incision was made in the abdominal region and the abdominal aorta was exposed. The abdominal aorta was occluded in the subrenal region using non-traumatic aneurysm clips for $30 \mathrm{~min}$, and reperfusion was confirmed by observation under a stereoscope. The body temperature was tightly regulated $\left(38.7 \pm 0.3^{\circ} \mathrm{C}\right)$ during ischemic surgery using a thermometric blanket connected to a rectal probe. Immediately after reperfusion, the rabbits received an intraperitoneal injection of Tat peptide $(2.5 \mathrm{mg} / \mathrm{kg})$, Control-PGAM1 protein, or Tat-PGAM1 protein (both $2.5 \mathrm{mg} / \mathrm{kg}$ ). The dosage of Tat-PGAM1 was determined by previous studies showing the neuroprotective effects of Tat-PGAM1 against ischemic damage [21] and translation of dosage $(10 \mathrm{mg} / \mathrm{kg} \times 3 / 12)[50]$.

Physiological parameters, such as $\mathrm{PaO}_{2}, \mathrm{PaCO}_{2}, \mathrm{pH}$, and glucose were analyzed using a GEM Premier 3000 (Instrumentation Laboratory, Milan, Italy) before and $10 \mathrm{~min}$ after reperfusion. In addition, the mean arterial pressure (MAP) was measured from the coccygeal artery. The neurological status was evaluated based on the Tarlov criteria [51] 24 and $72 \mathrm{~h}$ after reperfusion as described in previous studies $[8,49]$, because postural abnormalities were found $12-24 \mathrm{~h}$ after ischemia; complete paraplegia was seen $48 \mathrm{~h}$ after ischemia [52,53].

To observe the neuroprotective effects of Tat-PGAM1 and Control-PGAM1 against ischemic damage, the surviving neurons and microglia were visualized using immunohistochemical staining for NeuN and Iba-1 in the ventral horn of the spinal cord, respectively, as described in a previous study [54]. The rabbits were re-anesthetized with $5 \%$ isoflurane 3 and $7 \mathrm{~d}$ after reperfusion and perfused transcardially with physiological saline and $4 \%$ PFA. Lumbar spinal cord $\left(\mathrm{L}_{6}-\mathrm{L}_{7}\right)$ was removed from the vertebral column and post-fixed in the same fixative for $24 \mathrm{~h}$. Spinal tissue was dehydrated with ethanol, cleared with xylene, and embedded in paraffin wax. Coronal sections ( $4 \mu \mathrm{m}$ thickness) were prepared and sections were incubated with mouse anti-NeuN (1:1000; EMD Milipore, Temecula, CA, USA) and anti-Iba-1 (1:100; Abcam, Cambridge, UK) for $48 \mathrm{~h}$ at $4{ }^{\circ} \mathrm{C}$. Thereafter, sections were sequentially incubated with goat anti-mouse IgG and a streptavidin-peroxidase complex (1:200; Vector, Burlingame, CA, USA) for $2 \mathrm{~h}$ at $25^{\circ} \mathrm{C}$. Sections were visualized by reaction with $3,3^{\prime}$-diaminobenzidine tetrachloride (Sigma), hydrated with ethanol, and mounted with Canada balsam (Junsei. Chemical, Tokyo, Japan).

\subsection{Anti-Oxidative and Anti-Inflammatory Effects of Tat-PGAM1 against Ischemic Damage in Rabbits}

Oxidative damage induced by spinal cord ischemia was assessed by measuring MDA and 8-iso-PGF $2 \alpha$, which are generated by the peroxidation of polyunsaturated fatty acid and arachidonic acid in the membrane, respectively $[55,56]$. The inflammatory response induced by spinal cord ischemia was evaluated by measuring pro-inflammatory cytokines, such as IL-1 $\beta$, IL-6, and TNF- $\alpha$. Briefly, animals ( $n=5$ per group) were anesthetized using $5 \%$ isoflurane, and the lumbar spinal cords $\left(\mathrm{L}_{6}-\mathrm{L}_{7}\right)$ were obtained. MDA (Cayman Chemical Company, Ann Arbor, MI, USA), 8-iso-PGF2 $\alpha$ (Cayman Chemical Company), IL-1 $\beta$ (Cusabio, Hubei, China), IL-6 (Cusabio), and TNF- $\alpha$ (R\&D 
Systems Inc., Minneapolis, MN, USA) ELISA assay kits were used to measure the oxidative indicators and pro-inflammatory cytokines as per the manufacturer instructions.

\subsection{Data Quantification and Analysis}

The number of NeuN-positive cells was counted in the ventral horn of the spinal cord using Optimas 6.5 image analysis software (CyberMetrics Corporation, Phoenix, AZ, USA). Ten sections were analyzed to count NeuN-positive cells in the spinal cord, and the average number of NeuN-positive cells was noted.

The Iba-1 immunoreactivity was analyzed using Image J software version 1.50 (National Institutes of Health, Bethesda, MD, USA), as described previously [20,21]. Images taken from Iba-1 immunoreactive structures were calibrated to 256 gray scale, and unlabeled structures were subtracted using Adobe Photoshop 2020 software. The pixel number and immunodensity were measured using ImageJ, and the optical density of Iba-1-immunoreactive structures was calculated. All optical densities were represented as percentile values versus the control group (set as $100 \%$ ).

All data shown are presented as the mean \pm standard deviation. Differences in the means were compared and statistically analyzed using one-way or two-way analysis of variance (ANOVA), followed by Bonferroni's post hoc test using GraphPad Prism 5.01 software (GraphPad Software, Inc., La Jolla, CA, USA).

Author Contributions: H.Y.J., H.J.K, W.K., K.R.H., S.M.M., Y.S.Y., D.W.K., and I.K.H. conceived the study. H.Y.J., H.J.K, D.W.K., and I.K.H. designed the study and wrote the manuscript. H.Y.J., W.K., and K.R.H. conducted the animal experiments. H.J.K. and D.W.K. conducted the biochemical experiments. S.M.M. and Y.S.Y. participated in designing and discussing the study. All authors have read and agreed to the published version of the manuscript.

Funding: This work was supported by Basic Science Research Program through the National Research Foundation of Korea (NRF) funded by the Ministry of Education (NRF-2019R1A6A3A01095031) and by the Korea government (MSIT) (KRF-2018R1A2B6001941). In addition, this work was supported by the Research Institute for Veterinary Science, Seoul National University.

Conflicts of Interest: The authors declare no conflict of interest. The funders had no role in the design of the study; in the collection, analyses, or interpretation of data; in the writing of the manuscript, or in the decision to publish the results.

\section{References}

1. De Lavor, M.S.; Binda, N.S.; Fukushima, F.B.; Caldeira, F.M.; da Silva, J.F.; Silva, C.M.; de Oliveira, K.M.; Martins Bde, C.; Torres, B.B.; Rosado, I.R.; et al. Ischemia-reperfusion model in rat spinal cord: Cell viability and apoptosis signaling study. Int. J. Clin. Exp. Pathol. 2015, 8, 9941-9949. [PubMed]

2. Xiao, W.; Wen, J.; Huang, Y.C.; Yu, B.S. Development of a modified model of spinal cord ischemia injury by selective ligation of lumbar arteries in rabbits. Spinal Cord 2017, 55, 1028-1032. [CrossRef] [PubMed]

3. Romi, F.; Naess, H. Spinal cord infarction in clinical neurology: A review of characteristics and long-term prognosis in comparison to cerebral infarction. Eur. Neurol. 2016, 76, 95-98. [CrossRef] [PubMed]

4. Lynch, D.R.; Dawson, T.M.; Raps, E.C.; Galetta, S.L. Risk factors for the neurologic complications associated with aortic aneurysms. Arch. Neurol. 1992, 49, 284-288. [CrossRef]

5. Basu, S.; Hellberg, A.; Ulus, A.T.; Westman, J.; Karacagil, S. Biomarkers of free radical injury during spinal cord ischemia. FEBS Lett. 2001, 508, 36-38. [CrossRef]

6. Smith, P.D.; Puskas, F.; Meng, X.; Lee, J.H.; Cleveland, J.C., Jr.; Weyant, M.J.; Fullerton, D.A.; Reece, T.B. The evolution of chemokine release supports a bimodal mechanism of spinal cord ischemia and reperfusion injury. Circulation 2012, 126, S110-S117. [CrossRef]

7. Garcia, E.; Aguilar-Cevallos, J.; Silva-Garcia, R.; Ibarra, A. Cytokine and growth factor activation in vivo and in vitro after spinal cord injury. Mediat. Inflamm. 2016, 2016, 9476020. [CrossRef]

8. Kim, W.; Cho, S.B.; Jung, H.Y.; Yoo, D.Y.; Oh, J.K.; Choi, G.M.; Cho, T.G.; Kim, D.W.; Hwang, I.K.; Choi, S.Y.; et al. Phosphatidylethanolamine-binding protein 1 ameliorates ischemia-induced inflammation and neuronal damage in the rabbit spinal cord. Cells 2019, 8, 1370. [CrossRef] 
9. Chen, C.; Shaw, Y.S. Cyclic metabolic pathway of a butylated hydroxytoluene by rat liver microsomal fractions. Biochem. J. 1974, 144, 497-501. [CrossRef]

10. Fothergill-Gilmore, L.A.; Watson, H.C. The phosphoglycerate mutases. Adv. Enzymol. Relat. Areas Mol. Biol. 1989, 62, 227-313.

11. Sultana, R.; Perluigi, M.; Newman, S.F.; Pierce, W.M.; Cini, C.; Coccia, R.; Butterfield, D.A. Redox proteomic analysis of carbonylated brain proteins in mild cognitive impairment and early Alzheimer's disease. Antioxid. Redox Signal. 2010, 12, 327-336. [CrossRef] [PubMed]

12. Sharif, F.; Rasul, A.; Ashraf, A.; Hussain, G.; Younis, T.; Sarfraz, I.; Chaudhry, M.A.; Bukhari, S.A.; Ji, X.Y.; Selamoglu, Z.; et al. Phosphoglycerate mutase 1 in cancer: A promising target for diagnosis and therapy. IUBMB Life 2019, 71, 1418-1427. [CrossRef] [PubMed]

13. Kondoh, H.; Lleonart, M.E.; Gil, J.; Wang, J.; Degan, P.; Peters, G.; Martinez, D.; Carnero, A.; Beach, D. Glycolytic enzymes can modulate cellular life span. Cancer Res. 2005, 65, 177-185. [PubMed]

14. Takahashi, Y.; Takahashi, S.; Yoshimi, T.; Miura, T. Hypoxia-induced expression of phosphoglycerate mutase B in fibroblasts. Eur. J. Biochem. 1998, 254, 497-504. [CrossRef] [PubMed]

15. Kondoh, H.; Lleonart, M.E.; Bernard, D.; Gil, J. Protection from oxidative stress by enhanced glycolysis; a possible mechanism of cellular immortalization. Histol. Histopathol. 2007, 22, 85-90. [PubMed]

16. Iyer, N.V.; Kotch, L.E.; Agani, F.; Leung, S.W.; Laughner, E.; Wenger, R.H.; Gassmann, M.; Gearhart, J.D.; Lawler, A.M.; Yu, A.Y.; et al. Cellular and developmental control of $\mathrm{O}_{2}$ homeostasis by hypoxia-inducible factor 1 alpha. Genes Dev. 1998, 12, 149-162. [CrossRef]

17. Niizeki, H.; Kobayashi, M.; Horiuchi, I.; Akakura, N.; Chen, J.; Wang, J.; Hamada, J.I.; Seth, P.; Katoh, H.; Watanabe, H.; et al. Hypoxia enhances the expression of autocrine motility factor and the motility of human pancreatic cancer cells. Br. J. Cancer 2002, 86, 1914-1919. [CrossRef]

18. Schwarze, S.R.; Ho, A.; Vocero-Akbani, A.; Dowdy, S.F. In vivo protein transduction: Delivery of a biologically active protein into the mouse. Science 1999, 285, 1569-1572. [CrossRef]

19. Zhang, X.; Zhang, X.; Wang, F. Intracellular transduction and potential of Tat PTD and its analogs: From basic drug delivery mechanism to application. Expert Opin. Drug Deliv. 2012, 9, 457-472. [CrossRef]

20. Jung, H.Y.; Kwon, H.J.; Kim, W.; Nam, S.M.; Kim, J.W.; Hahn, K.R.; Yoo, D.Y.; Won, M.H.; Yoon, Y.S.; Kim, D.W.; et al. Phosphoglycerate mutase 1 promotes cell proliferation and neuroblast differentiation in the dentate gyrus by facilitating the phosphorylation of cAMP response element-binding protein. Neurochem. Res. 2019, 44, 323-332. [CrossRef]

21. Kim, W.; Kwon, H.J.; Jung, H.Y.; Yoo, D.Y.; Kim, D.W.; Hwang, I.K. Phosphoglycerate mutase 1 reduces neuronal damage in the hippocampus following ischemia/reperfusion through the facilitation of energy utilization. Neurochem. Int. 2020, 133, 104631. [CrossRef] [PubMed]

22. Cashman, N.R.; Durham, H.D.; Blusztajn, J.K.; Oda, K.; Tabira, T.; Shaw, I.T.; Dahrouge, S.; Antel, J.P. Neuroblastoma x spinal cord (NSC) hybrid cell lines resemble developing motor neurons. Dev. Dyn. 1992, 194, 209-221. [CrossRef] [PubMed]

23. Boyd-Kimball, D.; Sultana, R.; Poon, H.F.; Lynn, B.C.; Casamenti, F.; Pepeu, G.; Klein, J.B.; Butterfield, D.A. Proteomic identification of proteins specifically oxidized by intracerebral injection of amyloid beta-peptide (1-42) into rat brain: Implications for Alzheimer's disease. Neuroscience 2005, 132, 313-324. [CrossRef] [PubMed]

24. Sharma, N.K.; Sethy, N.K.; Bhargava, K. Comparative proteome analysis reveals differential regulation of glycolytic and antioxidant enzymes in cortex and hippocampus exposed to short-term hypobaric hypoxia. J. Proteom. 2013, 79, 277-298. [CrossRef]

25. Peinado, M.Á.; Hernández, R.; Peragón, J.; Ovelleiro, D.; Pedrosa, J.Á.; Blanco, S. Proteomic characterization of nitrated cell targets after hypobaric hypoxia and reoxygenation in rat brain. J. Proteomics 2014, 109, 309-321. [CrossRef]

26. Imperlini, E.; Orrù, S.; Corbo, C.; Daniele, A.; Salvatore, F. Altered brain protein expression profiles are associated with molecular neurological dysfunction in the PKU mouse model. J. Neurochem. 2014, 129, 1002-1012. [CrossRef]

27. Yu, H.; Jiang, X.; Lin, X.; Zhang, Z.; Wu, D.; Zhou, L.; Liu, J.; Yang, X. Hippocampal subcellular organelle proteomic alteration of copper-treated mice. Toxicol. Sci. 2018, 164, 250-263. [CrossRef]

28. Guyton, K.Z.; Liu, Y.; Gorospe, M.; Xu, Q.; Holbrook, N.J. Activation of mitogen-activated protein kinase by $\mathrm{H}_{2} \mathrm{O}_{2}$. Role in cell survival following oxidant injury. J. Biol. Chem. 1996, 271, 4138-4142. [CrossRef] 
29. Lander, H.M. An essential role for free radicals and derived species in signal transduction. FASEB J. 1997, 11, 118-124. [CrossRef]

30. Fan, Z.; Wang, X.; Zhang, M.; Zhao, C.; Mei, C.; Li, P. MAPK Pathway Inhibitors Attenuated Hydrogen Peroxide Induced Damage in Neural Cells. Biomed Res. Int. 2019, 2019, 5962014. [CrossRef]

31. Daugas, E.; Susin, S.A.; Zamzami, N.; Ferri, K.F.; Irinopoulou, T.; Larochette, N.; Prévost, M.C.; Leber, B.; Andrews, D.; Penninger, J.; et al. Mitochondrio-nuclear translocation of AIF in apoptosis and necrosis. FASEB J. 2000, 14, 729-739. [CrossRef] [PubMed]

32. Zwerschke, W.; Mazurek, S.; Stöckl, P.; Hütter, E.; Eigenbrodt, E.; Jansen-Dürr, P. Metabolic analysis of senescent human fibroblasts reveals a role for AMP in cellular senescence. Biochem. J. 2003, 376, 403-411. [CrossRef] [PubMed]

33. Sakamoto, M.; Takaki, E.; Yamashita, K.; Watanabe, K.; Tabuchi, S.; Watanabe, T.; Satoh, K. Nonenzymatic derived lipid peroxide, 8-iso-PGF2 alpha, participates in the pathogenesis of delayed cerebral vasospasm in a canine SAH model. Neurol. Res. 2002, 24, 301-306. [CrossRef] [PubMed]

34. Kertmen, H.; Celikoglu, E.; Ozturk, O.C.; Gürer, B.; Bozkurt, H.; Kanat, M.A.; Arikok, A.T.; Erguder, B.I.; Sargon, M.F.; Sekerci, Z. Comparative effects of methylprednisolone and tetracosactide (ACTH1-24) on ischemia/reperfusion injury of the rabbit spinal cord. Arch. Med. Sci. 2018, 14, 1459-1470. [CrossRef]

35. Hitosugi, T.; Zhou, L.; Elf, S.; Fan, J.; Kang, H.B.; Seo, J.H.; Shan, C.; Dai, Q.; Zhang, L.; Xie, J.; et al. Phosphoglycerate mutase 1 coordinates glycolysis and biosynthesis to promote tumor growth. Cancer Cell 2012, 22, 585-600. [CrossRef]

36. Kelly, B.; O'Neill, L.A. Metabolic reprogramming in macrophages and dendritic cells in innate immunity. Cell Res. 2015, 25, 771-784. [CrossRef]

37. Gaber, T.; Strehl, C.; Buttgereit, F. Metabolic regulation of inflammation. Nat. Rev. Rheumatol. 2017, 13, $267-279$. [CrossRef]

38. Ip, W.K.E.; Hoshi, N.; Shouval, D.S.; Snapper, S.; Medzhitov, R. Anti-inflammatory effect of IL-10 mediated by metabolic reprogramming of macrophages. Science 2017, 356, 513-519. [CrossRef]

39. Zhang, J.M.; An, J. Cytokines, inflammation, and pain. Int. Anesthesiol. Clin. 2007, 45, 27-37. [CrossRef]

40. Teixeira, J.M.; de Oliveira-Fusaro, M.C.; Parada, C.A.; Tambeli, C.H. Peripheral P2 $\times 7$ receptor-induced mechanical hyperalgesia is mediated by bradykinin. Neuroscience 2014, 277, 163-173. [CrossRef]

41. Sun, S.; Chen, D.; Lin, F.; Chen, M.; Yu, H.; Hou, L.; Li, C. Role of interleukin-4, the chemokine CCL3 and its receptor CCR5 in neuropathic pain. Mol. Immunol. 2016, 77, 184-192. [CrossRef] [PubMed]

42. Sun, Y.; Yang, M.; Tang, H.; Ma, Z.; Liang, Y.; Li, Z. The over-production of TNF- $\alpha$ via Toll-like receptor 4 in spinal dorsal horn contributes to the chronic postsurgical pain in rat. J. Anesth. 2015, 29, 734-740. [CrossRef] [PubMed]

43. Haque, A.; Capone, M.; Matzelle, D.; Cox, A.; Banik, N.L. Targeting enolase in reducing secondary damage in acute spinal cord injury in rats. Neurochem. Res. 2017, 42, 2777-2787. [CrossRef] [PubMed]

44. Glass, C.K.; Saijo, K.; Winner, B.; Marchetto, M.C.; Gage, F.H. Mechanisms underlying inflammation in neurodegeneration. Cell 2010, 140, 918-934. [CrossRef]

45. Yang, Y.W.; Wang, Y.L.; Lu, J.K.; Tian, L.; Jin, M.; Cheng, W.P. Delayed xenon post-conditioning mitigates spinal cord ischemia/reperfusion injury in rabbits by regulating microglial activation and inflammatory factors. Neural Regen. Res. 2018, 13, 510-517.

46. Shechter, R.; London, A.; Varol, C.; Raposo, C.; Cusimano, M.; Yovel, G.; Rolls, A.; Mack, M.; Pluchino, S.; Martino, G.; et al. Infiltrating blood-derived macrophages are vital cells playing an anti-inflammatory role in recovery from spinal cord injury in mice. PLoS Med. 2009, 6, e1000113. [CrossRef]

47. Sahin, M.A.; Onan, B.; Guler, A.; Oztas, E.; Uysal, B.; Arslan, S.; Demirkilic, U.; Tatar, H. Cilostazol, a type III phosphodiesterase inhibitor, reduces ischemia/reperfusion-induced spinal cord injury. Heart Surg. Forum 2011, 14, E171-E177. [CrossRef]

48. Song, J.; Baek, I.J.; Chun, C.H.; Jin, E.J. Dysregulation of the NUDT7-PGAM1 axis is responsible for chondrocyte death during osteoarthritis pathogenesis. Nat. Commun. 2018, 9, 3427. [CrossRef]

49. Kim, W.; Kwon, H.J.; Jung, H.Y.; Yoo, D.Y.; Moon, S.M.; Kim, D.W.; Hwang, I.K. Tat-HSP70 protects neurons from oxidative damage in the NSC34 cells and ischemic damage in the ventral horn of rabbit spinal cord. Neurochem. Int. 2019, 129, 104477. [CrossRef]

50. Reagan-Shaw, S.; Nihal, M.; Ahmad, N. Dose translation from animal to human studies revisited. FASEB J. 2008, 22, 659-661. [CrossRef] 
51. Tarlov, I.M. Spinal Cord Compression; Mechanism of Paralysis and Treatment; Charles C. Thomas Publisher: Springfield, IL, USA, 1957.

52. Moore, W.M., Jr.; Hollier, L.H. The influence of severity of spinal cord ischemia in the etiology of delayed-onset paraplegia. Ann. Surg. 1991, 213, 427-431. [CrossRef] [PubMed]

53. Wisselink, W.; Patetsios, P.; Panetta, T.F.; Ramirez, J.A.; Rodino, W.; Kirwin, J.D.; Zikria, B.A. Medium molecular weight pentastarch reduces reperfusion injury by decreasing capillary leak in an animal model of spinal cord ischemia. J. Vasc. Surg. 1998, 27, 109-116. [CrossRef]

54. Jung, H.Y.; Kim, D.W.; Kwon, H.J.; Yoo, D.Y.; Hwang, I.K.; Won, M.H.; Cho, T.G.; Choi, S.Y.; Moon, S.M. SUMO-1 delays neuronal damage in the spinal cord following ischemia/reperfusion. Mol. Med. Rep. 2017, 15, 4312-4318. [CrossRef] [PubMed]

55. Esterbauer, H.; Schaur, R.J.; Zollner, H. Chemistry and biochemistry of 4-hydroxynonenal, malonaldehyde and related aldehydes. Free Radic. Biol. Med. 1991, 11, 81-128. [CrossRef]

56. Morrow, J.D.; Hill, K.E.; Burk, R.F.; Nammour, T.M.; Badr, K.F.; Roberts, L.J., 2nd. A series of prostaglandin F2-like compounds are produced in vivo in humans by a non-cyclooxygenase, free radical-catalyzed mechanism. Proc. Natl. Acad. Sci. USA 1990, 87, 9383-9387. [CrossRef]

(C) 2020 by the authors. Licensee MDPI, Basel, Switzerland. This article is an open access article distributed under the terms and conditions of the Creative Commons Attribution (CC BY) license (http://creativecommons.org/licenses/by/4.0/). 